\title{
First approach to understanding riparian wetlands in the Middle Ebro River floodplain (NE, Spain): Structural characteristics and functional dynamics
}

\author{
Belinda Gallardo *, Mercedes García, Álvaro Cabezas, Eduardo González, Cecilia Ciancarelli, \\ María González and Francisco A. Comín
}

Pyrinean Institute of Ecology (CSIC). Avda. de Montañana 1005, Zaragoza. 50192. Tfno: 9760716034 Fax: 976716019

*Corresponding author: belinda@ipe.csic.es

\begin{abstract}
First approach to understanding riparian wetlands in the Middle Ebro River floodplain (NE, Spain): structural characteristics and functional dynamics

In Spring of 2005, the relationships between the physical and chemical characteristics of the aquatic and benthic environments and macroinvertebrate assemblages in seven wetlands representative of the floodplain of the Middle Ebro River (NE Spain), were analyzed. The selected wetlands differed in their hydrological connectivity, local environmental conditions and anthropic influence. Through multivariate analyses, two environmental gradients and three main wetland groups were detected. The hydrological connectivity differences generate a heterogenous landscape of structurally and functionally different wetlands in the Ebro Middle floodplain. Confined wetlands, such as older ox bow lakes, showed higher salt and organic matter contents and lower macroinvertebrates' density and biodiversity than did the other wetlands. This suggests that confinement and lack of disturbance events have led to water salinization and eutrophication, habitat homogenization and natural succession of the communities towards more adapted structures with lower biodiversity. Wetlands that still maintain some functional relationship with the river, such as newer ox bow lakes, constructed wetlands, and backwaters, show a higher inorganic nutrient concentration and suspended solids. They also show higher taxa richness and evenness, which suggests that higher disturbance frequencies enhance habitat's heterogeneity and resource availability, and therefore primary and secondary production that allow adapted and opportunistic species to coexist. The progressive flow regulation tends to homogenise this complex system, endangering its conservation. Therefore, the key processes identified here should be taken under consideration for the planning and execution of ecological monitoring, management and restoration.
\end{abstract}

Key words: Macroinvertebrates, riparian wetlands, Ebro River, hydrological connectivity, eutrophication, water turnover.

\section{RESUMEN}

Enfoque preliminar para entender los humedales riparianos en la llanura media del Ebro (NE, Spain): características estructurales y dinámica funcional

En primavera de 2005 se analizaron las relaciones entre las características físicas y químicas de los medios acuático y bentónico, y la comunidad de macroinvertebrados de 7 humedales representativos de la llanura de inundación del río Ebro (NE de España) en su tramo medio. Los humedales seleccionados se diferenciaron por su grado de conectividad hídrica, condiciones ambientales locales e influencia antrópica. Mediante análisis multivariante, se localizaron dos gradientes ambientales y tres tipos de humedales principales. Las diferencias de conectividad hidrológica generan un mosaico heterogéneo de humedales con diferente estructura y función en la llanura de inundación del Ebro Medio. Los humedales confinados -como los meandros abandonados más antiguos- mostraron mayor contenido de sales y materia orgánica, y menor densidad y diversidad de macroinvertebrados que el resto de humedales. Esto sugiere que el confinamiento y la falta de eventos de perturbación han conducido a la salinización y eutrofización del agua, la homogeneización del hábitat y la sucesión natural de las comunidades hacia estructuras más adaptadas y de menor diversidad. Los humedales que todavía mantienen cierta relación funcional con el río -como los meandros abandonados más recientes, humedales artificiales y "madres"- muestran una mayor concentración de nutrientes inorgánicos y sólidos en suspensión, además de una mayor riqueza de taxones y equitatividad, lo que sugiere que la mayor frecuencia de perturbación favorece la heterogeneidad de 
hábitat y de recursos, y por tanto la producción primaria y secundaria permitiendo la coexistencia de especies oportunistas y adaptadas. La progresiva regulación de caudales tiende a homogeneizar este complejo sistema poniendo en peligro su conservación. Por tanto, los procesos principales identificados en este estudio deben ser tenidos en cuenta en el diseño de planes de monitoreo, gestión y restauración ecológicas.

Palabras clave: Macroinvertebrados, humedales riparios, río Ebro, conectividad hidrológica, eutrofización, renovación del agua.

\section{INTRODUCTION}

In the last 20 years, the effects of disturbance events on river floodplains have been a subject of major interest in limnology (Amoros \& Roux 1988; Heiler et al., 1995; Ward \& Stanford 1995; Stanford et al., 1996; Ward et al., 1999). River floodplains are characterized by high habitat diversity and a highly diverse biota that are adapted to the spatial and temporal heterogeneity of the ecosystem (Tockner et al., 1999a, 2000b; Junk et al, 1989; Poff et al., 1997). Most of the world's floodplains are subjected to intense disturbances that have come to be due to modifications to river flow and human-induced changes in land use (Welcomme, 1992; Denysius \& Nilsson, 1994). In Europe, the hydrological pulses and connectivity of most of the riverine wetlands are greatly restricted because of surface flooding and a decrease in the groundwater level caused by extensive impoundments and water extraction (Petts et al., 1989). At the ecosystem level, the consequences include a lack of rejuvenation in biological communities, and the salinization and eutrophication of waters. At a landscape scale, there is a minor possibility that a creation of new wetlands will occur, and those that remain, are endangered by low hydrological connectivity and high terrestrialization rates.

Disturbed hydrological cycles can lead to longer periods of stability and the confinement of riparian wetlands, which results in a natural succession toward adaptive communities with low biodiversity (Gasith \& Resh, 1999). The Intermediate Disturbance Hypothesis (HDI, Connell, 1978) predicts that higher species diversity is expected in water bodies that are connected at an intermediate frequency (Amoros \& Bornette,
1999; Ward et al., 1999); however, this species diversity also depends on the nutrient status of the water body, organism input, and habitat availability (Amoros \& Bornette, 2002).

Frequently, macroinvertebrates are used to assess the ecological integrity of wetlands (Reice \& Wohlenberg, 1993; Resh et al., 1995) because of the vulnerability, ubiquity, and life cycle of these species (Basset et al., 2004). Since the early 20th Century, various approaches have been used to describe macroinvertebrate communities and the effects of hydrological factors (Gasith \& Resh, 1999), such as biodiversity indices and functional feeding groups (FFG), which are often used to assess community structure and ecosystem-level processes (Merrit et al., 1999; Rawer-Jost et al., 2000; Gayraud et al., 2003).

This study examined the relationships between the physical, chemical, and biological characteristics of riparian wetlands in the Middle Ebro River floodplain (NE Spain). The environmental problems of the Ebro River are similar to those of other rivers in Europe; in the past 150 years, humans have canalized, polluted, and impounded the river for agricultural, urban, and industrial purposes. The floodplains have been hydrologically disconnected from the main river but, in the middle section, the flow of the Ebro River is relatively variable, with a few large floods ( $>800 \mathrm{~m}^{3} / \mathrm{s}$ ) between October and March. At the landscape scale, the combination of disturbance pulses and natural river succession in the Middle Ebro River floodplain has created numerous wetlands that have varying degrees of hydrological connection as, for example, secondary channels, backwaters, oxbow lakes, and temporary pools (Ollero, 1996). Our principal objectives were to establish a preliminary classifica 
tion of wetlands that have varying degrees of connectivity with the river channel and to define the main factors that regulate their characteristics.

\section{MATERIALS AND METHODS}

In this study, seven wetlands in the Middle Ebro River floodplain (four ox-bow lakes, two backwater channels, and an artificial wetland, figure 1) were chosen based on their local environmental conditions, hydrological connectivity (location and topography relative to the river and other potential water inflows), and direct anthropogenic influences (including management and restoration activities) (Table 1). At each wetland, sampling stations were established at three points (upstream, mid-stream, and downstream). The Ebro River is the main source of water, or- ganisms, and energy to riparian wetlands through flow and flood pulses. Therefore, the river was monitored at a point near the centre of the study area. Wetland dissimilarities from the River were supposedly dependant on duration of isolation and the development of biological interactions.

In the spring of 2005, water and sediment samples from sampling stations and the main channel of the Ebro River, as well as macroinvertebrates from various habitats at these sites were collected. Dissolved oxygen, temperature, conductivity, and $\mathrm{pH}$ were measured in situ using portable probes (WTW ${ }^{\mathrm{R}}$ Multiline $\left.\mathrm{P} 4\right)$. Water samples were collected at a depth of $20 \mathrm{~cm}$, directly into acid-washed bottles, and refrigerated with ice until analysis. Alkalinity was determined immediately using potentiometric automatic titration with $\mathrm{H}_{2} \mathrm{SO}_{4} 0.04 \mathrm{~N}$ (APHA, 1989). Water samples were filtered through pre-
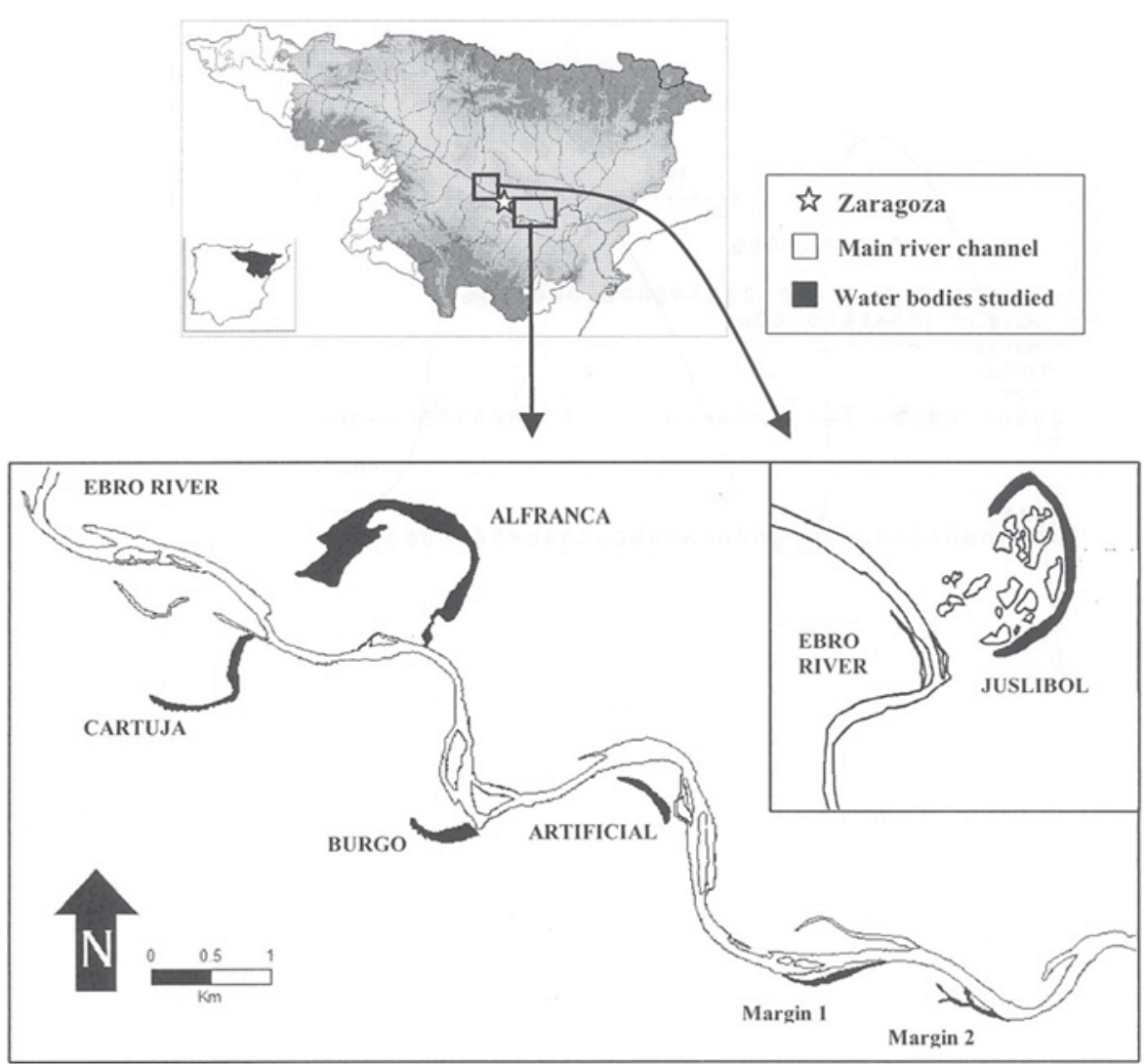

Figure 1. Location of the study area in the Middle Ebro River floodplain (NE Spain). Localización del área de estudio en el tramo medio del río Ebro (NE España). 
Table 1. Main characteristics of 7 riparian wetlands and the Ebro River in its middle stretch (NE Spain). Depth = mean depth $(\mathrm{m})$, Aq. Veg. = aquatic vegetation, Subs. = substrate, Area $=$ in ha, $\mathrm{CA}=$ cluster membership, $1=$ isolated wetlands, $2=$ connected wetlands, $3=$ intermediate wetlands, $\mathrm{P}=$ Phragmites australis, $\mathrm{T}=$ Typha latifolia, $\mathrm{R}$ = riparian vegetation, $\mathrm{H}=$ herbaceous grassland, and $\mathrm{L}=$ littoral areas without vegetation, $\mathrm{C}=$ cobbles, $\mathrm{G}=$ gravel, $\mathrm{S}$ $=$ silt. Principales características de los 7 humedales riparios estudiados y el río Ebro en su tramo medio (NE España). Depth = profundidad media $(\mathrm{m})$, Aq. Veg. = vegetación acuática, Subs. = substrato, Area $=$ en ha., $C A=$ cluster de pertenencia, $1=$ humedales aisladas, 2 = humedales conectadas, $3=$ humedales intermedias, $P=$ Phragmites australis, $T=$ Typha latifolia, $R=$ vegetación de ribera, $H=$ pradera de herbáceas y $L=$ orilla sin vegetación, $C=$ cantos, $G=$ gravas, $S=$ limo .

\begin{tabular}{|l|c|c|c|c|c|}
\hline Name & Depth & Aq. Veg. & Subst. & Area & CA. \\
\hline Ebro & - & P,T,R,L & C + G & 125.5 & - \\
\hline Margin 2 & 1 & $\mathrm{~T}$ & $\mathrm{~S}$ & 2.14 & 2 \\
\hline Margin 1 & 0.5 & $\mathrm{~T}, \mathrm{P}, \mathrm{H}, \mathrm{L}$ & $\mathrm{G}+\mathrm{S}$ & 3.14 & 2 \\
\hline Juslibol & 2 & $\mathrm{P}, \mathrm{T}, \mathrm{H}$ & $\mathrm{S}+\mathrm{G}$ & - & 2 \\
\hline Artificial & 3 & $\mathrm{P}, \mathrm{T}, \mathrm{R}$ & $\mathrm{G}$ & 3.34 & 3 \\
\hline Alfranca & 2 & $\mathrm{P}, \mathrm{T}$ & $\mathrm{S}$ & 36.99 & 3 \\
\hline Burgo & 0.5 & $\mathrm{P}, \mathrm{R}$ & $\mathrm{S}$ & 4.46 & 1 \\
\hline Cartuja & 2 & $\mathrm{P}$ & $\mathrm{S}$ & 6.33 & 1 \\
\hline
\end{tabular}

combusted $\left(450^{\circ} \mathrm{C}, 4 \mathrm{~h}\right)$ Whattman ${ }^{\circledR} \mathrm{GF} / \mathrm{F}$ glass fibre filters for the retrieval of suspended, dissolved, and ash-free solids (APHA, 1989). Filtrated sub samples were stored frozen, and ionic chromatography was later used to determine nutrient and anion contents (APHA, 1989). Another saturated filter was stored frozen, and, the spectrophotometer method was then used to analyse photosynthetic pigments (APHA, 1989).

In each wetland, with the exception of the main river channel (where the dredge was not suited to the gravel substratum), three sediment cores were collected and, on the same day, the conductivity, $\mathrm{pH}$, organic content $\left(500^{\circ} \mathrm{C}, 2 \mathrm{~h}\right)$, and extractable nutrients were measured using standard methods (SSSA, 1996).

At various microhabitats within each wetland, a Surber sampler $(0.500 \mu \mathrm{m}$ sieve, 20 kicks method) was used to collect invertebrates. The microhabitats included emergent vegetation (e.g., Phragmites australis and Typha latifolia, which formed dense stands along the edges of the water bodies), coarse organic matter comprising packs of leaf litter, littoral areas free of vegetation and having a silt or gravel substratum, and stagnant areas along the river margin. Samples were preserved in $5 \%$ formalin and, later, washed through nested sieves $(2500 \mu \mathrm{m}, 1000 \mu \mathrm{m}$, and $500 \mu \mathrm{m})$. Organisms were hand-sorted, identified, and enumerated (Dussart 1967, 1969; Wiederholm 1983, 1986; Alonso 1996; Meish, 2000; Tachet et al., 2000). To evaluate the ecological characteristics of the macroinvertebrate communities, a set of metrics were used, including diversity indexes (Shannon-Wiener Index and taxa richness), dominant species, and functional feeding groups (FFG, Yosimura et al., 2006).

SPSS 13.0 and CANOCO 4.5 were used for univariate and multivariate statistical analyses respectively. Variables were checked individually using box-plots, coefficients of normality, and variance homogeneity. When necessary, chemical data were transformed using $\log _{10}(100 x+1)$. To assign the wetlands to homogeneous groups, a cluster analysis (Ward Method) was performed and, to identify the major factors discriminating the groups of wetlands (clusters), the data were subjected to Principal Component Analysis (PCA, with varimax rotation, after ruling out variables that were highly correlated). An analysis of variance (Kruskal-Wallis test) was used to identify significant differences among wetland groups for hydrochemical and biological variables. A preliminary analysis of the abundance of taxa (Detrended Correspondence Analysis, DCA) showed a strong unimodal response in the species gradients ( $>4$ standard deviations), which indicated that a unimodal analysis, the Detrended Canonical Correspondence Analysis (DCCA), was suitable for the data set (ter Braak, 1987). To avoid problems of colinearity, highly correlated environmental variables were excluded from the analysis until inflation factors were below 20 (critical value). The abundances of genera were transformed using square root $(\sqrt{x})$ and down-weighed for rare taxa. Once the principal axes were extracted, their significance was tested using a Monte Carlo permutation test (Hope, 1968). 


\section{RESULTS}

In the riparian wetlands examined, the water was highly mineralized $\left(242 \pm 73 \mathrm{mg} / \mathrm{HCO}_{3}^{-}\right)$, had high conductivity $(1814 \pm 864 \mu \mathrm{S} / \mathrm{cm})$, and had a slightly basic $\mathrm{pH}(7.84 \pm 0.31)$. Those characteristics are influenced by the geological materials that the river washes through its watershed (calcareous and gypsy marls), which release bicarbonates and adsorb phosphates. The values from the middle and the extremes of each wetland were highly heterogeneous, possibly, due to littoral influence at sampling points near the edges (upstream and downstream), but the differences were not statistically significant (oneway ANOVA, $p>0.05$ ). The high turbidity evident in most of the wetlands might have been the result of re-suspension (wind and fish perturbation) and high algal productivity (mean $19.99 \pm 19.43 \mu \mathrm{g} / \mathrm{l}$ Chla- $a$ ). The intensive agricultural land use on the left margin of the river specially affects the Alfranca oxbow lake, where the hydrology follows nonnatural patterns, including higher water tables in summer (the irrigation period) than in winter (river flood period), and higher nitrogen concen-

Table 2. Physical, chemical, and biological characteristics of water and sediments of 7 riparian wetlands and the Ebro River in its middle stretch (NE Spain). Type I = isolated, Type II = connected, Type III = semi-connected, Type IV = river, $-=$ no data available. Significant (*: $p<0.05$, **: $p<0.01$ ) and non-significant (n.s.: $p>0.05$ ) differences between wetland types and the Ebro River are shown (Kruskal-Wallis test). Características físicas, químicas y biológicas del agua y del sedimento de los 7 humedales riparios $y$ el río Ebro en su tramo medio (NE España). Tipo $I=$ confinados, Tipo $I I=$ conectados, Tipo $I I I=$ semi-conectados, Tipo $I V=$ río, $-=$ datos no disponibles. Se muestran las diferencias significativas $(*: p<0.05$, **: $p<0.01)$ y no significativas (n.s.: $p>0.05)$ encontradas entre los diferentes tipos de humedales y el río (Kruskal-Wallis test).

\begin{tabular}{|c|c|c|c|c|c|c|c|c|c|}
\hline & Type & vetlands & & Type II wetland & & Type III & wetlands & er & Sig. K-W \\
\hline & CARTUJA & BURGO & MARGIN 1 & MARGIN 2 & JUSLIBOL & ALFRANCA & ARTIFICIAL & EBRO & \\
\hline $\mathbf{T}\left({ }^{\circ} \mathbf{C}\right)$ & $19.53(0.06)$ & $17.33(1.51)$ & $17.35(0.78)$ & $17.27(1.44)$ & $16.17(0.46)$ & $13.67(0.21)$ & $14.50(0.75)$ & $15.33(2.91)$ & $* * \mathrm{I}>\mathrm{II}>\mathrm{IV}>\mathrm{III}$ \\
\hline $\mathrm{pH}$ & $66(0.18)$ & $7.41(0.10)$ & $7.83(0.28)$ & $8.15(0.29)$ & $7.80(0.11)$ & $7.54(0.03)$ & $8.03(0.06)$ & $8.16(0.08)$ & $* *$ IV $>$ II $>$ III $>$ I \\
\hline Cond $(\mu s / \mathrm{cm})$ & $3253(6)$ & $2347(262)$ & $1850(172)$ & 1575 (234) & $961.0(30.3)$ & $2740(61)$ & $1238(18)$ & $709.0(139.2)$ & $* * \mathrm{I}>\mathrm{III}>\mathrm{IV}>\mathrm{II}$ \\
\hline $\mathrm{O}_{2}(\mathrm{mg} / \mathrm{l})$ & $6.58(2.04)$ & $7.48(1.16)$ & $10.66(5.61)$ & $7.83(4.19)$ & $8.01(1.23)$ & $10.32(1.15)$ & $8.49(0.38)$ & $9.22(1.01)$ & n.s. \\
\hline TSS (mg/l) & $20.31(0.76)$ & $24.60(2.41)$ & $129.1(121.7)$ & $33.20(27.40)$ & $12.87(3.93)$ & $14.80(10.28)$ & $5.80(2.84)$ & $27.13(26.95)$ & n.s. \\
\hline TDS (mg/l) & $2729(86)$ & $1961(248)$ & $922.5(92.6)$ & $1164(246)$ & $474.7(248.3)$ & $1867(53)$ & $736.3(113.8)$ & $472.0(94.1)$ & $* * \mathrm{I}>\mathrm{III}>\mathrm{II}>\mathrm{IV}$ \\
\hline $\mathrm{HCO}_{3}^{-}(\mathrm{mg} / \mathrm{l})$ & $207.0(26.3)$ & $191.3(14.4)$ & $254.3(2.3)$ & $274.9(15.3)$ & $238.3(5.5)$ & $368.8(5.6)$ & $263.6(20.9)$ & $134.5(97.4)$ & $* *$ III $>$ II $>$ I $>$ IV \\
\hline $\mathrm{NO}_{2}^{-}(\mathrm{mg} / \mathrm{l})$ & $0.11(0.02)$ & 0.20 & 0 & 0. & 1) & 2) & 2) & $0.09(0.03)$ & $* \mathrm{I}>\mathrm{II}>\mathrm{IV}>\mathrm{III}$ \\
\hline $\mathrm{NO}_{3}^{-}(\mathrm{mg} / \mathrm{l})$ & 7) & 6. & 4 & 1 & 2 & ) & 2.6 & 28) & n.s. \\
\hline $\mathrm{NH}_{4}^{+}(\mathrm{mg} / \mathrm{l})$ & $0.17(0.15)$ & $0.11(0.05)$ & $0.09(0.12)$ & $0.15(0.09)$ & $0.06(0.02)$ & $14(0.10)$ & $0.09(0.05)$ & $0.25(0.12)$ & n.s. \\
\hline Norg & 3) & 0.90 & $0.66(0.17)$ & 1.2 & 5) & 1) & 0 & 4) & n.s. \\
\hline $\mathbf{P O}_{4}^{3-}(\mu \mathrm{g} / \mathrm{l})$ & $9.7(109.9)$ & $232.7(15.0)$ & $293.5(7.8)$ & 301.0 (113.6) & $210.7(17.1)$ & $216.3(12.5)$ & $219.0(5.6)$ & $218.7(17.0)$ & n.s. \\
\hline P org & 128. & 77.7 & 2 & 20.1 & 0 & $68.1(24.5)$ & 6.8 & 2) & $* * \mathrm{I}>\mathrm{III}>\mathrm{I}$ \\
\hline $\mathrm{SO}_{4}^{=}(\mathrm{mg} / \mathrm{l})$ & 1847 (113) & $1318(120)$ & $465.2(330.3)$ & 408.5 (148.9) & $234.4(62.5)$ & $647.6(8.2)$ & $297.6(17.6)$ & $108.4(28.3)$ & $* * \mathrm{I}>\mathrm{III}>\mathrm{II}>\mathrm{IV}$ \\
\hline Chl- $a(\mu \mathrm{g} / \mathrm{l})$ & $29.23(3.20)$ & $5.47(0.38)$ & 35.20 & $53.45(22.58)$ & $32.08(0.73)$ & $7.71(0.98)$ & $2.99(1.27)$ & $17.92(17.91)$ & n.s. \\
\hline Chl-b $(\mu \mathrm{g} / \mathrm{l})$ & $0.24(0.42)$ & $0.91(1.57)$ & 0.00 & $0.89(1.52)$ & $0.08(0.14)$ & $0.72(0.56)$ & $0.41(0.71)$ & $0.48(0.60)$ & n.s. \\
\hline TSI (CHL) & $63.67(1.05)$ & $47.26(0.68)$ & 64.96 & $68.94(4.68)$ & $64.62(0.22)$ & $50.59(1.21)$ & $40.81(3.98)$ & $62.57(10.01)$ & $* *$ II $>$ IV $>$ I $>$ III \\
\hline TSI (TP) & $81.52(3.25)$ & $76.62(3.10)$ & $72.57(3.86)$ & $69.83(5.06)$ & $65.28(1.19)$ & $75.18(2.85)$ & $67.02(2.35)$ & $72.96(2.55)$ & $* * \mathrm{I}>\mathrm{III}>\mathrm{IV}>\mathrm{II}$ \\
\hline TSI (TN) & $58.10(5.66)$ & $66.87(2.80)$ & $61.95(4.52)$ & $73.07(1.54)$ & 55.39 & $86.01(9.86)$ & $53.41(8.19)$ & $69.23(1.97)$ & n.s. \\
\hline pH & $8.53(0.13)$ & $8.08(0.31)$ & $8.25(0.07)$ & $8.49(0.15)$ & $8.40(0.06)$ & $8.10(0.00)$ & $8.72(0.43)$ & - & n.s. \\
\hline Cond $(\mu \mathrm{S} / \mathrm{cm})$ & $337.3(50.5)$ & 1480 (1094) & $164.3(12.02)$ & $293.33(100.18)$ & $261.67(21.82)$ & $337.66(50.65)$ & $170.20(44.77)$ & - & $* * \mathrm{I}>\mathrm{III}>\mathrm{II}$ \\
\hline O.M. (\%) & $9.90(3.11)$ & $5.19(3.26)$ & $4.00(1.16)$ & $6.25(1.95)$ & $4.69(0.71)$ & $9.05(3.16)$ & $4.36(2.00)$ & - & n.s. \\
\hline
\end{tabular}




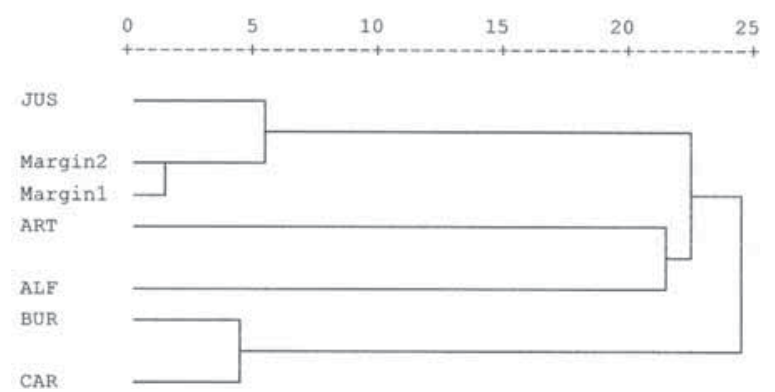

Figure 2. Dichotomic diagram that clusters the wetlands of the Middle Ebro River floodplain (NE Spain) into homogeneous groups. ALF $=$ Alfranca, $\mathrm{ART}=$ Artificial, $\mathrm{BUR}=$ Burgo, $\mathrm{CAR}$ $=$ Cartuja, JUS $=$ Juslibol. Diagrama dicotómico que agrupa los humedales de la llanura media del río Ebro (NE España) en grupos homogéneos. ALF = Alfranca, ART = Artificial, BUR = el Burgo, CAR = Cartuja, JUS $=$ Juslibol.

trations (mean $17.94 \pm 0.09 \mathrm{mg} / \mathrm{N} \mathrm{NO}_{3}^{-}$) than in the wetlands on the right margin of the river (mean $4.69 \pm 1.65 \mathrm{mg} / \mathrm{l} \mathrm{NO}-$ ).

\section{Wetland types and major environmental factors}

To establish a broad classification of the wetlands in the Middle Ebro River floodplain, we subjected the hydrochemical data to cluster and principal component analyses. The first three principal factors of the PCA accounted for $66.9 \%$ of the initial variance. Total dissolved solids, organic phosphorous, sediment organic content, and sediment conductivity were highly correlated with the first component (30.3\% of initial variance) (Table 3). We consider this an eutrophication gradient, as far as the variables best correlated with this factor are directly related to confinement and nutrient enrichment. On the other hand, DIN (as the sum of $\mathrm{NO}_{3}^{-}, \mathrm{NO}_{2}^{-}$, and $\mathrm{NH}_{4}^{+}$), bicarbonates, and organic nitrogen were more strongly correlated with the second component $(21 \%$ of the initial variance), whereas phosphate, dissolved oxygen, and suspended solids were more closely associated with the third component (18.7\% of the initial variance). Both axes might be associated with high water turnover because the river is the main source of those compounds. The cluster analyses identified three principal groups of wetlands (Fig. 2 and Table 2), which were clearly separated along the first and second PCA axes (Fig. 3).
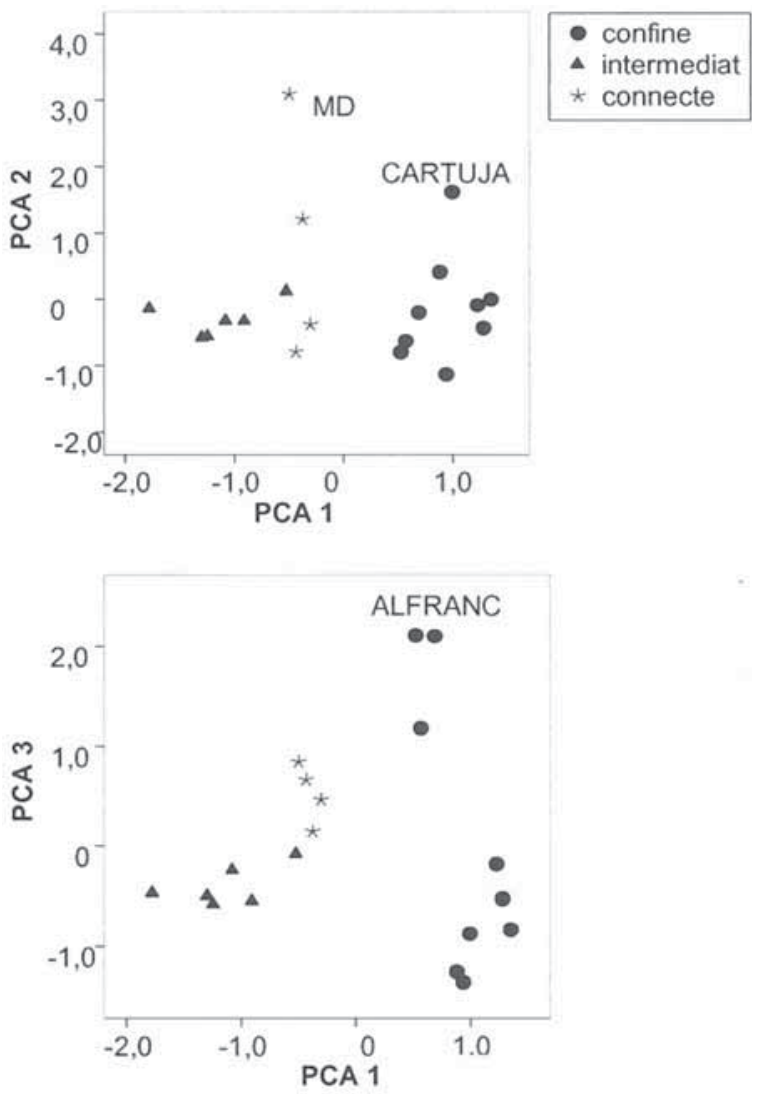

Figure 3. Ordination graph of the aquatic systems, plotting (A) principal factors 1 and 2; (B) factors 1 and 3 using data from 7 riparian wetlands and the Ebro River in its middle stretch (NE Spain). Gráfico de ordenación de los sistemas acuáticos, mostrando (A) los factores principales 1 y 2; (B) los factores 1 y 3, utilizando datos de los 7 humedales riparios y el río Ebro en su tramo medio (NE España).

Type 1 wetlands (confined), which included the Cartuja and Burgo sites were old wetlands that had very low hydrological connectivity. In the PCA, those wetlands are on the right side of the first environmental gradient (eutrophy), and exhibited higher salt and organic nutrient accumulations. The compaction of their highly organic sediments (8.7-10.0\% organic content) and low groundwater tables limit subsurface flow, which causes a loss in the functional relationship with the main river channel. In addition, Type 1 wetlands had relatively high dissolved solids (2345 $\pm 452 \mathrm{mg} / \mathrm{l}$, hereafter values in brackets are group means, individual values can be consulted in Table 2) and organic phosphorous concentrations $(103 \pm 55 \mu \mathrm{g} / \mathrm{l})$. 
Table 3. Environmental variables extracted in the PCA with an eigenvalue $>0.5$ in rotated axes using the data from 7 riparian wetlands and the Ebro River in its middle stretch (NE Spain). Variables ambientales extraídas en el ACP con un peso superior a 0.5 en los ejes rotados, utilizando los datos de los 7 humedales riparios y el río Ebro en su tramo medio (NE España).

\begin{tabular}{l|rrrr}
\hline Variable & \multicolumn{4}{|c}{ Component } \\
\hline TDS & $\mathbf{1}$ & $\mathbf{2}$ & $\mathbf{3}$ & $\mathbf{4}$ \\
Sed. \% O.M. & 0.915 & & & \\
Sed. Cond. & 0.909 & & & \\
P org & 0.847 & & & \\
DIN & -0.687 & & & \\
HCO & & 0.869 & & \\
N org & & 0.866 & & \\
Sed. pH & & 0.828 & & \\
PO- & & & & \\
O $_{\mathbf{2}}^{\text {3- }}$ & & & 0.899 & \\
Chl- $\boldsymbol{a}$ & & & -0.886 & \\
TSS & & & & \\
Chl- $\boldsymbol{b}$ & & & & -0.524 \\
\hline
\end{tabular}

Type 2 wetlands (connected) are backwaters and new ox-bow lakes that are connected to the main river channel by surface and subsurface flows. The Juslibol oxbow lake, and the Margin 1, and Margin 2 backwaters were in this group. They were at an intermediate position on PCA factor 1 (eutrophy) and covered a wide range of PCA factor 2 (water turnover) than the other wetlands did. The Type 2 wetlands had characteristics similar to those of the Ebro River, including high alkalinity $\left(267 \pm 16 \mathrm{mg} / \mathrm{l} \mathrm{HCO}_{3}^{-}\right)$, suspended solids (72 $\pm 83 \mathrm{mg} / \mathrm{l} \mathrm{TSS})$, and inorganic nutrients $(1.84 \pm 0.77 \mathrm{mg} / \mathrm{l} \mathrm{DIN} ; 260 \pm 30$ $\mathrm{mg} / \mathrm{l} \mathrm{PO}_{4}^{3-}$ ), which were heterogeneous in time and space. In those wetlands, the sediments had low organic content (4.55-6.19\%) and the water column had both low organic phosphorus $(8.00$ $\pm 8.05 \mu \mathrm{g} / \mathrm{l})$ and organic nitrogen $(0.30 \pm 0.43$ $\mathrm{mg} / \mathrm{l})$ concentrations.

Type 3 (semi-connected) wetlands, which included the Artificial and Alfranca sites, were in an intermediate state between the confined (Type 1) and connected (Type 2), wetlands. Type 3 wetlands were characterized as having lower eco-hydrological connections than type 2 wetlands did, but high water turnover. The Alfranca oxbow lake is temporally connected with the river channel downward during high flow and upward during floods (river flow higher than 300 and $800 \mathrm{~m}^{3} \cdot \mathrm{s}^{-1}$ respectively, personal observation). The Artificial site is a created wetland that has a subsurface connection to the Ebro River because of its permeable gravel substratum. Type 3 wetlands are on the left side of the first PCA axis (eutrophy) and have values on the second axis (water turnover) that are slightly higher than those of confined wetlands. Furthermore, they had low values of $\mathrm{NO}_{2}^{-}(0.08 \pm$ $0.02 \mathrm{mg} / \mathrm{l}), \mathrm{PO}_{4}^{3-}(218 \pm 9 \mu \mathrm{g} / \mathrm{l})$, and chlorophyll $a(5.35 \pm 2.77 \mu \mathrm{g} / \mathrm{l})$, but intermediate levels of dissolved solids and sediment organic content. The high concentrations of nitrate in Alfranca are the product of agricultural irrigation discharges in the surrounding area.

\section{Aquatic macroinvertebrate communities}

In the seven wetlands and the Ebro River, 40 macroinvertebrate samples were collected, which included 27400 individuals in 105 taxa. Sixteen taxa $(15 \%)$ were zooplankters (copepods, water fleas, and seed shrimps). Although microcrustaceans belong to a different functional trophic level, they were included in the multivariate analyses because their relatively high abundance in these very shallow ecosystems makes them an important component of these wetland communities. The most common taxa included microcrustaceans such as Acanthocyclops trajani (present in 9 of 9 wetlands) and Ilyocryptus sordidus (8/9), water bugs, such as Micronecta sp. (9/9), and aquatic worms of the Naididae family (8/9). The relative abundances of different taxonomical groups (without microcrustaceans for better comparison) and FFG for every wetland can be observed in Table 4, figures 4 and 5.

Non parametric analysis of variance (KruskalWallis test) showed that Oligochaeta were significantly more abundant in semi-connected wetlands, while Ephemeroptera (e.g., Caenis luctuosa, Cloeon scriptum), Macrocrustacea (e.g., Procambarus clarkii, Atyaephira desmarestii), and Trichoptera (e.g. Ecnomus spp., Hydropsyche spp.) were significantly more abundant in the Ebro River. Among various habitats, Macrocrustacea were most abundant in patches of emergent macrophytes (Phragmites australis and Typha latifolia), while Ephemeroptera were 


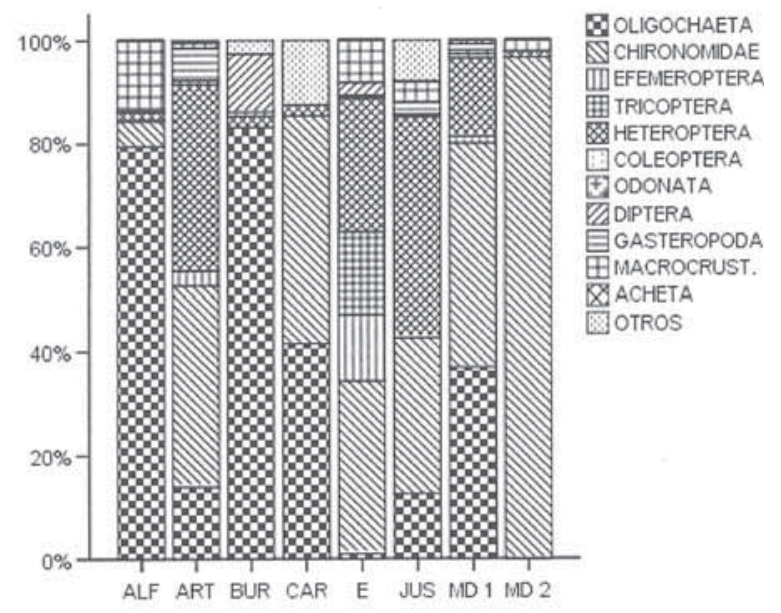

Figure 4. Abundance composition (percentage of individuals' ${ }^{\circ}$ ) of the macroinvertebrate communities of 7 riparian wetlands and the Ebro River in its middle stretch (NE Spain). Microinvertebrates are not shown. ALF $=$ Alfranca, $\mathrm{ART}=\mathrm{Ar}-$ tificial, BUR $=$ Burgo, CAR $=$ Cartuja, $\mathrm{E}=$ Ebro river, JUS = Juslibol, MD1 = Margin 1, MD2 = Margin2. Composición de abundancias (porcentaje del $n^{o}$ de individuos) de las comunidades de macroinvertebrados de los 7 humedales riparios y el río Ebro en su tramo medio (NE España). Los microinvertebrados no están incluidos. ALF = Alfranca, ART = Artificial, $B U R=$ el Burgo, $C A R=$ Cartuja $E=$ río Ebro, JUS $=$ Juslibol, $M D 1=$ Margen $1, M D 2=$ Margen 2.

more abundant in sites that had a gravel substratum rather than fine bottom sediments, where Oligochaeta were significantly predominant ( $p<0.05$ in Kruskal-Wallis test).

The variance explained by the multivariate DCCA model accounted for $40.4 \%$ of the initial species-environmental relationship variance. Two main environmental gradients are useful in explaining the distribution of the water bodies studied, similar to those founded in the PCA previously presented. On the first axis (horizontal axis in figure 6), eutrophy increased from left to right, as did organic nutrients, chlorophyll $a$, and sediment organic content. On the second axis (vertical axis in figure 6), water turnover increased from the bottom to the top, as reflected by dissolved inorganic nutrients, dissolved oxygen, and total suspended solids, which are the variables most strongly associated with this axis. Analysis of variance (Kruskal Wallis test) and DCCA analyses indicated that the types of wetlands differed significantly in their assemblage parameters (Table 4).

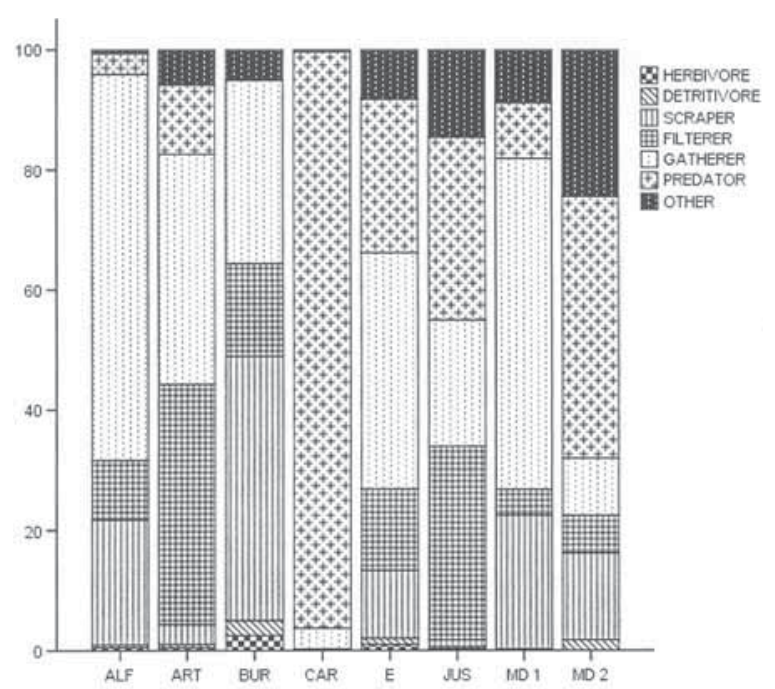

Figure 5. Composition of the macroinvertebrates communities of 7 riparian wetlands and the Ebro River in its middle stretch (NE Spain) based on feeding behaviour (percentage of $\mathrm{FFG}) . \mathrm{ALF}=$ Alfranca, $\mathrm{ART}=$ Artificial, $\mathrm{BUR}=$ Burgo, $\mathrm{CAR}=$ Cartuja, $\mathrm{E}=$ Ebro River, JUS = Juslibol, MD1 = Margin 1, MD2 = Margin2. Composición de las comunidades de macroinvertebrados de los siete humedales riparios y el río Ebro en su tramo medio (NE España), en base a sus formas de alimentación (porcentaje de FFG). ALF = Alfranca, ART = Artificial, $B U R=e l$ Burgo, $C A R=$ Cartuja, $E=$ río Ebro, JUS = Juslibol, $M D 1=$ Margen 1, MD2 = Margen2.

Genera richness, diversity, and evenness were significantly higher in the Ebro River than in any of the other wetlands studied. Those characteristics might be associated with higher habitat diversity and disturbance pulses in the main river channel than in the riparian wetlands. The abundances of Ephemeroptera and Trichoptera were higher in the Ebro River than they were in the other wetlands, in part, because gravel is the dominant substratum in the river, whereas fine sediments predominate in the stagnant wetlands of the floodplain. Connected wetlands had significantly higher diversity and evenness than semiconnected and confined wetlands did. In the area defined by the first two factors of the DCCA, the connected wetlands were at intermediate levels on factor 1 (eutrophy) and at high levels on factor 2 (water turnover). They were dominated by microcrustaceans (e.g., Macrocyclops albidus) (56\%), quironomids (e.g., Paratanytarsus spp.) (22\%), and water bugs (16\%). The dominant feeding groups were predators $(37 \%)$, 
Table 4. Characteristics of the macroinvertebrate assemblages of 7 riparian wetlands and the Ebro River in its middle stretch (NE Spain). Type I = isolated, Type II = connected, Type III = semi-connected, and Type IV = Ebro River. Significant $(*: p<0.05$, **: $p<0.01$ ) and non-significant (n.s.: $p>0.05$ ) differences between wetland types and the Ebro River are shown (Kruskal-Wallis test). Características de la comunidad de macroinvertebrados de los 7 humedales riparios y el río Ebro en su tramo medio (NE España). Tipo $I=$ confinados, Tipo II = conectados, Tipo III= Semi-conectados y Type IV = Río Ebro. Se muestran las diferencias significativas (*: $p<0.05$, **: $p<0.01)$ y no significativas (n.s.: $p>0.05$ ) encontradas entre los diferentes tipos de humedales y el río (KruskalWallis test).

\begin{tabular}{|c|c|c|c|c|c|c|c|c|c|}
\hline & \multicolumn{2}{|c|}{ Type I wetlands } & \multicolumn{3}{|c|}{ Type II wetlands } & \multicolumn{2}{|c|}{ Type III wetlands } & \multirow{2}{*}{$\begin{array}{c}\text { IV River } \\
\text { EBRO }\end{array}$} & \multirow[t]{2}{*}{ Sig. K-W } \\
\hline & CARTUJA & BURGO & MARGIN 1 & MARGIN 2 & JUSLIBOL & ALFRANCA & ARTIFICIAL & & \\
\hline Acheta & - & - & $0.76(1.31)$ & - & - & - & $0.15(0.30)$ & - & n.s. \\
\hline Chironomidae & $43.91(35.88)$ & - & $43.43(35.38)$ & $96.67(5.77)$ & $30.08(33.21)$ & $4.88(6.93)$ & $38.76(34.36)$ & $32.75(24.61)$ & n.s. \\
\hline Coleoptera & - & - & $0.76(1.31)$ & - & - & $0.07(0.19)$ & - & $0.36(0.66)$ & n.s. \\
\hline Diptera & - & $11.21(22.41)$ & - & - & $0.43(1.22)$ & $0.17(0.45)$ & $0.67(1.24)$ & $2.38(5.83)$ & n.s. \\
\hline Efemeroptera & - & - & $1.37(1.21)$ & - & - & $0.33(0.88)$ & $2.93(4.98)$ & $12.35(8.35)$ & $* *$ IV $>$ III $>$ II $>$ I \\
\hline Gasteropoda & - & - & $1.23(2.14)$ & - & $2.22(4.28)$ & $0.33(0.88)$ & $6.23(9.21)$ & - & n.s. \\
\hline Heteroptera & $2.08(5.89)$ & $2.08(4.17)$ & $15.21(18.90)$ & $1.11(1.92)$ & $42.68(32.24)$ & $1.31(1.92)$ & $36.01(34.01)$ & $25.32(37.51)$ & n.s. \\
\hline Macrocrustacea & - & - & - & $2.22(3.85)$ & $4.17(1.79)$ & $13.40(23.75)$ & $0.89(1.41)$ & $7.99(7.68)$ & $* *$ IV $>$ III $>$ II $>I$ \\
\hline Microcrustacea & 2086 & 23.88 & 58.67 & 77.33 & 46.97 & 28.82 & 342.50 & 157 & n.s. \\
\hline Odonata & - & $0.86(1.72)$ & $0.76(1.31)$ & - & - & - & $0.12(0.30)$ & $0.27(0.67)$ & n.s. \\
\hline Oligochaeta & $41.50(38.02)$ & $83.26(28.20)$ & $37.24(33.71)$ & - & $12.50(35.35)$ & $79.50(32.91)$ & $13.95(12.27)$ & $0.89(1.71)$ & $* *$ III $>$ I $>$ II $>$ IV \\
\hline Tricoptera & - & - & - & - & - & - & - & $15.61(24.43)$ & $* *$ IV $>$ I $>$ II $=$ III \\
\hline Others & $12.50(35.36)$ & $2.59(5.17)$ & - & - & $7.92(14.69)$ & - & $0.42(0.91)$ & - & n.s. \\
\hline Shannon div. & 2.27 & 1.23 & 2.34 & 2.12 & 2.07 & 1.55 & 1.24 & 2.32 & $* *$ IV $>$ II $>$ I $>$ III \\
\hline Evennes & 0.35 & 0.19 & 0.36 & 0.32 & 0.32 & 0.24 & 0.19 & 0.35 & $* *$ IV $>$ II $>$ I $>$ III \\
\hline Taxa Richness & 17 & 7 & 19 & 17 & 22 & 22 & 37 & 44 & $* *$ IV $>$ III $>$ II $>$ I \\
\hline Total abundance & 61 & 71 & 127 & 250 & 113 & 509 & 988 & 520 & $* *$ IV $>$ III $>$ II $>$ I \\
\hline Herbivore & $0.01(0)$ & $2.5(5.0)$ & $0.09(0.08)$ & 0 & $0.24(0.30)$ & $0.46(0.62)$ & $0.41(0.41)$ & $1.01(2.13)$ & n.s. \\
\hline Detritivore & $0.01(0)$ & $2.5(5.0)$ & $0.09(0.08)$ & $1.68(2.79)$ & $0.37(0.40)$ & $0.46(0.62)$ & $0.63(0.59)$ & $1.01(2.13)$ & n.s. \\
\hline Scraper & $0.08(0.14)$ & $43.96(13.73)$ & $22.33(16.27)$ & $14.50(13.59)$ & $1.1(1.50)$ & $20.84(19.5)$ & $0.33(0.27)$ & $11.33(6.84)$ & n.s. \\
\hline Filterer & $0.12(0.26)$ & $15.42(19.88)$ & $4.22(2.26)$ & $6.28(1.52)$ & $33.21(33.03)$ & $9.89(9.60)$ & $39.96(32.64)$ & $13.51(9.82)$ & $* *$ III $>$ II $>$ IV $>$ I \\
\hline Gathering-collector & $3.55(4.43)$ & $30.63(22.19)$ & $55.15(17.25)$ & $9.45(3.87)$ & $21.03(29.80)$ & $64.34(18)$ & $38.34(24.01)$ & $39.33(15.54)$ & $* *$ III $>$ IV $>$ II $>$ I \\
\hline Predator & $96.0(4.43)$ & 0 & $9.28(8.09)$ & $43.61(38.05)$ & $30.51(26.74)$ & $3.38(4.29)$ & $11.51(9.21)$ & $25.62(15.28)$ & n.s. \\
\hline Other FFG & $0.24(0.28)$ & $5.0(10.0)$ & $8.83(10.73)$ & $24.48(17.13)$ & $14.54(22.63)$ & $0.64(0.82)$ & $5.86(7.41)$ & $8.19(7.36)$ & $* \mathrm{II}>\mathrm{IV}>\mathrm{II}>\mathrm{I}$ \\
\hline
\end{tabular}

detritivores $(29 \%)$, and filterers $(16 \%)$. Semiconnected wetlands had significantly lower diversity and evenness scores, but had significantly higher genera richness (after the Ebro, which had the highest values) and abundance of macroinvertebrate than the other riparian wetlands did. In the DCCA, the semi-connected wetlands had the lowest values on factor 1 (eutrophy), but intermediate values on factor 2 (water turnover). Microcrustaceans (e.g., Simocephalus vetulus) (64\%) and water bugs (e.g., Micronecta spp.) (20\%) were the most abundant taxa, and filterers (51\%) and collectors $(35 \%)$ were the most abundant feeding groups. Confined wetlands had significantly lower values of genera richness and abun- dance, which indicated lower water quality and habitat diversity. Those wetlands were at high levels on factor 1 (eutrophy) and at low levels on factor 2 (water turnover). The densities of microcrustaceans were high $(97 \%)$ and most of these were Acanthocyclops trajani, Ilyocriptus sordidus, and Macrocyclops albidus. The dominant trophic group was predators (97\%).

In the wetlands of the Middle Ebro River, fish densities were high due to the stocking of sport fish. Cyprinus carpio and other exotic species are known to contribute to sediment re-suspension, and are directly associated with the growth inhibition of submerged plants (Scheffer, 1998). Recently, during three consecutive sampling days 

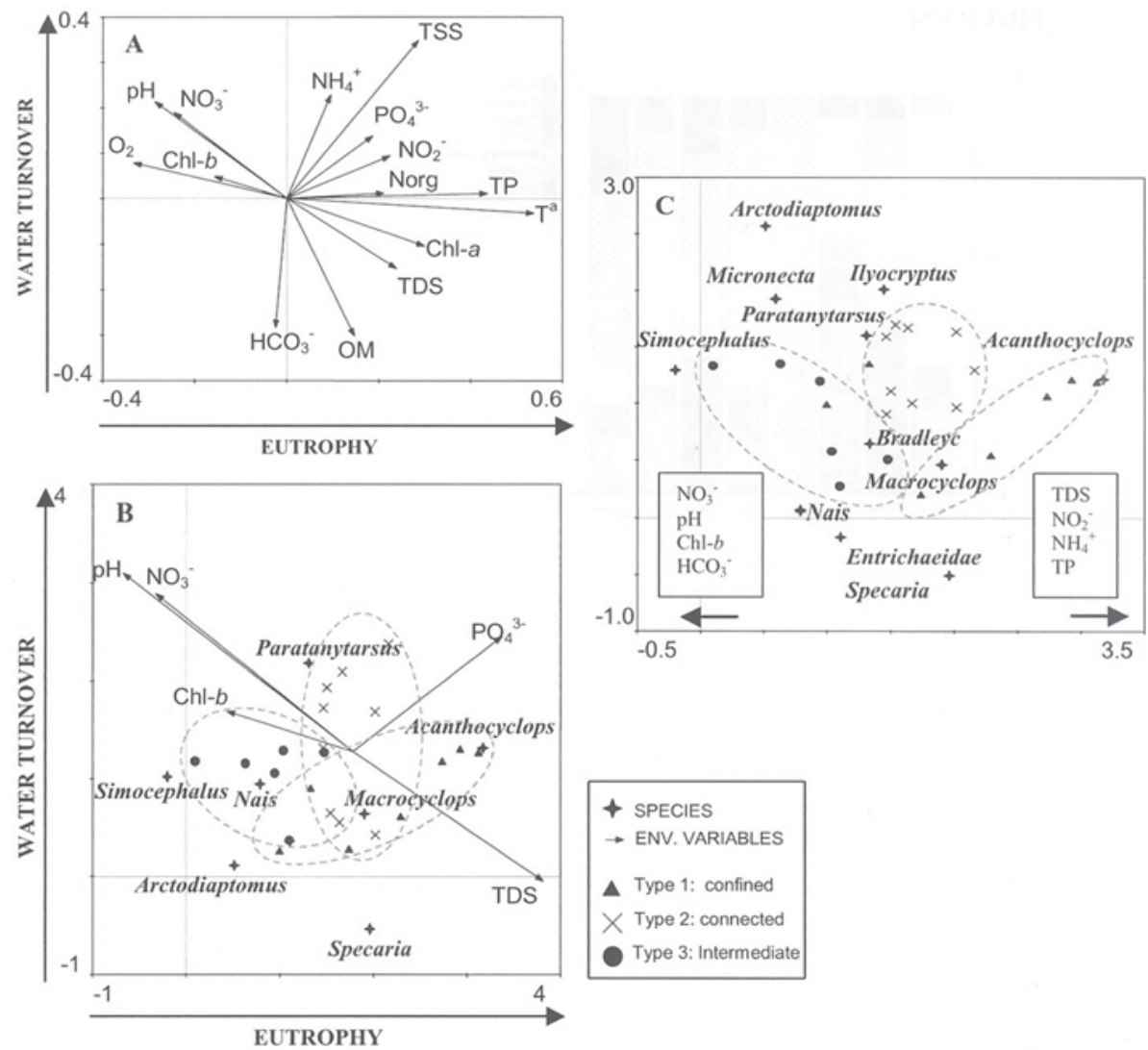

Figure 6. Ordination graph of the aquatic systems plotting (A y B) principal factors 1 and 2; (C) factors 1 and 3, using data from 7 riparian wetlands and the Ebro River in its middle stretch (NE Spain). Arrows indicate environmental variables, diamonds represent species, and samples are classified based on their hydrological connection (wetland type). Gráfico de ordenación de los sistemas acuáticos mostrando (A y B) los factores principales 1 y 2; (C) los factores 1 y 3, utilizando datos de los 7 humedales riparios y el río Ebro en su tramo medio (NE España). Las flechas representan variables ambientales, los rombos representan especies y los casos se muestran clasificados por su grado de conexión hidrológica (tipo de humedal).

( $5 \mathrm{~h}$ per day), using a $50 \mathrm{~m}$-long gill net fixed in the centre of the wetland, more than 114 individuals (46\% carp) were captured in the Alfranca ox-bow lake (36.9 ha.), which is a high density when compared to other Mediterranean wetlands (Blanco et al., 2003). Carp accounted for $94 \%$ of the total fish biomass, which underscores the importance of this fish in the control of ecosystem structure and function.

\section{DISCUSSION}

Our study of the environmental and community characteristics of water bodies in the Middle
Ebro River floodplain identified three types of wetlands. Connected wetlands (Juslibol, Margin 1, and Margin 2) were characterized by waters that had high total suspended solids, alkalinity, and inorganic dissolved nitrogen, as well as low conductivity, organic nutrient concentrations, and sediment organic content. Biodiversity and evenness were always high in connected wetlands, which suggest that high perturbation frequency leads to greater habitat heterogeneity (gravel and fine sediments, open water and emergent macrophyte areas, flowing and stagnant waters) and resource availability, enhancing primary and secondary production (Tockner et al., 1999b, 2000a). During perturbation events, connected 
wetlands become secondary channels of the river, and the river flow erodes the deposited material, exporting organic detritus and organisms to the fluvial system, as observed elsewhere (Gosselink et al., 1990; Mitsch \& Gosselink, 1993; Sharitz \& Mitsch, 1993). In addition, the higher proportions of predators, filterers and detritivores suggest that resource availability is higher there than in confined wetlands, which are dominated by predators.

Semi-connected wetlands are water bodies that were almost permanently connected to the river at the downstream end, and therefore frequently connected at both ends during high flows, e.g., backwaters and new ox-bow lakes. Low inorganic nutrient concentrations, low primary production, as well as intermediate levels of dissolved solids and sediment organic content characterize this wetland type. In semi-connected wetlands, water stability during periods of confinement favours natural succession, which is often disrupted by rejuvenation after hydrological events, thus, allowing adaptive and opportunistic species to coexist (Amoros \& Bornette, 1999; Ward et al., 1999). Those general characteristics are reflected in the higher macroinvertebrate abundances and taxa richness found in the semi-connected wetlands compared to those of the other wetlands in the Middle Ebro River floodplain.

Confined wetlands are water bodies where surface river water inflows are restricted to river floods $\left(>1000 \mathrm{~m}^{3} / \mathrm{s}\right)$, although they can receive intense groundwater discharges during periods of agricultural irrigation. This physical constraint favours the accumulation of salts and organic matter in the water column and in the sediment (which contributes to enrichment over time) and top-down control of the trophic web can be easily established by fish (Amoros \& Bornette 1999; Tockner et al., 1999b). Confined wetlands are characterized by a very highly eutrophic condition, involving high dissolved solids, organic phosphorous concentrations, and sediment organic content.

This study examined the water, sediment, and community characteristics of wetlands in the Middle Ebro River floodplain, NE Spain, in the context of two major forcing functions, trophic status and water turnover, which are important factors influencing wetland characteristics in other large river floodplains (Amoros \& Bornette 1999; Tockner et al., 1999a). In this study, the simple ordination of the wetlands into three groups reflects the relatively reduced ecological heterogeneity of the Middle Ebro River floodplain. The environmental gradients in other large river floodplains are higher and can involve a continuum of physical, chemical, and biological characteristics that represent types of environments not examined in our study (e.g., secondary channels, ox-bow lakes connected at the upstream side with the river water). These, would increase the number of community types including, for example, submerged macrophytedominated habitats, which are not found in the Middle Ebro River floodplain.

\section{CONCLUSIONS}

Three types of wetlands were identified in the Middle Ebro River floodplain, NE Spain. Confined wetlands (Cartuja and Burgo) were very isolated and eutrophic. These, received mainly groundwater discharges and were rich in nutrients due to agricultural practices. Semi-connected wetlands (Alfranca and Artificial) received seepage and backwater from the river during high floods and were characterized by a relatively rich biological community. Connected wetlands (Juslibol, Margin 1 and Margin 2) frequently received surface water from the river, and had high total suspended solids and low organic-rich sediments. They showed higher habitat complexity, which contributed to a relatively highly complex trophic web. This simple classification of wetlands indicates that other wetland types, among the entire range of environments and community types, characteristic of frequently and heavily flooded floodplains, are missing in the Middle Ebro Floodplain.

\section{ACKNOWLEDGEMENTS}

The authors are deeply thankful to the field and laboratory assistants, particularly M.L. Dehesa, B. Bueno and S. Pueyo, for their work 
and patience. This study is supported by the Spanish Ministry of Education (MEC CGL200507059-C02-01), the Departments of Environment and Science, Technology and the UniversityGovernment of Aragon (Collaboration Agreement 2005 and E-61 Research Group). Most of the authors are granted by the Government of Aragon, the Ministry of Education and CSIC.

\section{REFERENCES}

ALONSO, M. 1996. Fauna Ibérica: Crustacea Vol.7. M. A. Ramos, J. Alba, X. Bellés, J. Gonsálbes, A. Guerra, E. Macpherson, F. Martin, J. Serrano y J. Templado (eds.). Museo Nacional de Ciencias Naturales-CSIC, Madrid. 486 pp.

AMOROS, C. \& G. BORNETTE. 1999. Antagonistic and cumulative effects of connectivity: a predictive model based on aquatic vegetation in riverine wetlands. Arch. Hydrobiol., 11: 311-327.

AMOROS, M. \& G. BORNETTE. 2002. Connectivity and biocomplexity in water bodies of riverine floodplains. Freshwat. Biol., 47 (4): 761-776.

AMOROS, C. \& A. L. ROUX. 1988. Interaction between water bodies within the floodplain of large rivers: function and development of connectivity. Münst. Geo. Arb., 29:125-130.

APHA. 1989. Standard methods for the examination of water and wastewater. $17^{\mathrm{Th}}$ ed. American Public Health Association (APHA), Washington D. C., USA. 720 pp.

BASSET, Y., J. F. MAVOUNGOU, J. B. MIKISSA, O. MISSA, S. E. MILLER, R. L. KITCHING \& A. ALONSO. 2004. Discriminatory power of different arthropod data sets for the biological monitoring of anthropogenic disturbance in tropical forests. Biodiv. \& Cons., 13(4): 709-732.

BLANCO S., S. ROMO, M. J. VILLENA \& S. MARTÍNEZ. 2003. Fish communities and food web structure in some shallow Mediterranean lakes. Hydrobiologia., 506-509: 473-480.

CONNELL, J. H. 1978. Diversity in tropical rain forests and coral reefs. Science, 199: 1302-1310.

DENYSIUS, M. \& C. NILSSON. 1994. Fragmentation and flow regulation of river systems in the northern third of the world. Science, 266 : 753-762.

DUSSART, B. 1967. Les copépodes des eaux continentales d'Europe occidentale: Calanoides et
Harpacticoides. Vol 1.Faunes Et Flores Actuelles. 499 pp.

DUSSART, B. 1969. Les copépodes des eaux continentales d'Europe occidentale: Cyclopoides et Biologie. Vol 2. Faunes Et Flores Actuelles. 292 pp.

GASITH, A. \& V. H. RESH. 1999. Streams in Mediterranean Climate Regions: Abiotic influences and biotic responses to predictable seasonal events. Ann. Rew. Ecol. Syst., 30: 51-81.

GAYRAUD S., B. STATZNER B., P. BADY, A. HAYBACHP, F. SCHÖLL, P. USSEGLIOPOLATERA. \& M. BACCHI. 2003. Invertebrate traits for the biomonitoring of large European rivers. An initial assessment of alternative metrics. Freshwat. Biol., 48: 2045-2064.

GOSSELINK, J. G., L. C. LEE \& T. A. MUIR. 1990. Ecological processes and cumulative impacts: Illustrated by bottomland hard-wood wetland ecosystem. Lewis, Chelsea, Michigan. 708 pp.

HEILER, G., T. HEIN, F. SCHIEMER, \& G. BORNETTE. 1995. Hydrological connectivity and flood pulses as the control aspects for the integrity of a river-floodplain system. Reg. Rivers Res. \& Manage., 11:351-361.

HOPE, A. C. A. 1968. A Simplified Monte Carlo Significance Test Procedure. J. of the Royal Statistical Society. Series B-Statistical Methodology, 30(3): 582.

JUNK W. J., P. B. BALEY \& R. E. SPARKS 1989. The flood pulse concept in river floodplain systems. In: Proceedings of the large river symposium. D. P. Dodge (ed.). 106: 41-57. Canadian Special Publication on Fisheries and Aquatic Science.

MEISH, C. 2000. Freshwater Ostracada of Western and Central Europe. Spektrum Akademischer Verlag. 522 pp.

MERRIT, R. W., M. J. HIGGINS, K. W. CUMMINS \& B. VANDENEEDEN. 1999. The Kissimmee River-Riparian Marsh Ecosystem, Florida. Seasonal differences in invertebrate functional feeding group relationship. In: Invertebrates in freshwater wetlands of North America: ecology and management. D. P. Batzer, R. Rader \& S. A. Wissinger (eds.): 55-79. Wiley, New York.

MITSCH, W. J. \& J. G. GOSSELINK. 1993. Wetlands. Van Nostrand Reinhold, New York, 722 pp.

OLLERO, A. 1996. El curso medio del Ebro. Consejo De Protección De La Naturaleza de Aragón. Zaragoza, España. 311 pp. 
PETTS, G. E., H. MOLLER \& A. L. ROUX. 1989. (eds) Historical changes of large alluvial rivers: Western Europe. Wiley, Chichester, 355 pp.

POFF N. L., J. D. ALLAN, M. B. BAIN, J. R. KARR, K. L. PRESTEGAARD, B. D. RICHTE., R. E. SPARKS \& J. C. STROMBERG. 1997. The natural flow regime: a paradigm for conservation and restoration of river ecosystems. BioScience, 47: 769-784.

RAWER-JOST, C., J. BÖHMER, J. BLANJ \& H. RAMMAN. 2000. Macroinvertebrate functional feeding groups methods in ecological assessment. Hydrobiologia., 422/423: 225-232.

REICE, S. R. \& M. WOHLENBERG. 1993. Monitoring freshwater benthic macroinvertebrates and benthic processes: measures for assessment of ecosystem health. In: Freshwater biomonitoring and benthic Macroinvertebrates. Rosenberg D. M. \& Resh V. H. (eds.): 287-305. Chapman \& Hall, New York.

RESH, V. H., R. H. NORRIS \& M. T. BARBOUR. 1995. Design and implementation of rapid assessment approaches for water resource monitoring using benthic macroinvertebrates. Australian J. Ecol., 20: 108-121.

SCHEFFER, M. 1998. Ecology of Shallow Lakes. Chappman \& Hall: Population and Community Biology Series. Ed: M.B. Usher. London (UK). $357 \mathrm{pp}$.

SHARITZ, R. R. \& W. J. MITSCH. 1993. Southern floodplain forest. In: Biodiversity of the Southeastern United States. W. H. Martin, S.G. Boyce and A.C. Echternacht (eds.): 311-372. Wiley, New York. SSSA. 1996. Methods of soil analysis. Part 3: chemical methods. $4^{\text {Th }}$ ed. Soil Science Society of America (SSSA). Wisconsin, USA.

STANFORD, J. A., J. V. WARD, W. J. LISS, C. A. FRISSELL, R. N. WILLIAMS, J. A. LICHATOWICH \& C. C. COUTANT. 1996. A general protocol for restoration of regulated rivers. Reg. Rivers Res. \& Manag., 12: 391-413.

TACHET H., P. RICHOUX, M. BOURNAUD \& P. USSEGLIO-POLARETA. 2000. Invertébrés D'Eau Douce. CNRS Editions. 588 pp.

TER BRAAK, C. J. F. 1987. The Analysis of Vegetation-Environment Relationships by Canonical
Correspondence-Analysis. Vegetation, 69(1/3): 6977.

TOCKNER, K., F. SCHIEMER, C. BAUMGARTNER, G. KUM, E. WEIGAND, I. ZWEIMULLER \& J. V. WARD. 1999a. The Danube restoration project: Species diversity patterns across connec tivity gradients in the floodplain system. Reg. Rivers Res. \& Manag., 15: 245-258.

TOCKNER, K., D. PENNETZDOFER, N. REINER, F. SCHIEMMER \& J. V. WARD. 1999b. Hydrological connectivity and the exchange of organic matter and nutrient in a dynamic river-floodplain system (Danube-Austria). Freshwat. Biol., 41: 251-535.

TOCKNER K., F. MALARD \& J. V. WARD. 2000a. An extension of the flood pulse concept. Hydrol. Proc., 14: 2861-2883.

TOCKNER K., C. BAUMGARTNER, F. SCHIEMER \& J. V. WARD. 2000b. Biodiversity of a Danubian floodplain: structural, functional and compositional aspects,In: Biodiversity in wetlands: assessment, function and conservation. Vol. 1. Gopal B., Junk W. J. \& Davis J. A. (eds.): 141159. Backhuys Pub., Leiden (The Netherlands).

WELCOMME, R. L. 1992. River conservation-future prospects. In: River conservation and management. P. J. Boon, P. Calow \& E. Petts (eds.): 453-462. John Wiley \& Sons, Chichester, UK.

WARD, J. V. \& J. A. STANFORD. 1995. Ecological Connectivity in Alluvial River Ecosystems and Its Disruption by Flow Regulation. Reg. Rivers Res. \& Manage., 11: 105-119.

WARD, J. V., K. TOCKNER \& F. SCHIEMER. 1999. Biodiversity of floodplain river ecosystems: Ecotones and connectivity. Reg. Rivers Res. \& Manage., 15: 125-139.

WIEDERHOLM, T. 1983. Chironomidae Of The Holartic Region. Keys And Diagnosis. Part 1: Larvae. Entomología Escandinava. 457 pp.

WIEDERHOLM, T. 1986. Chironomidae Of The Holartic Region Keys And Diagnoses. Part 2: Pupae. Entomología Escandinava. 482 pp.

YOSHIMURA, C., K. TOCKNER, T. OMURA \& O. MOOG. 2006. Species diversity and functional assessment of macroinvertebrate communities in Austrian rivers. Limnology, 7(2): 63-74. 